\title{
Lawrence's Pursuit of True Life in Sons and Lovers
}

\author{
Chao Dun ${ }^{1, *}$
}

\author{
${ }^{1}$ Beihang University, Beijing, China \\ *Corresponding author. Email: dunchao@buaa.edu.cn
}

\begin{abstract}
Sons and Lovers not only makes the fame for D. H. Lawrence himself, but also is a highly biographical novel. Many scholars attempt to interpret it from the Freudian psychoanalytical perspective and regard the novel as the portrayal of Oedipus love between mother and son. Yet, that does not speak the essence for the novel and Lawrence's real intent in artistic creation. This paper will explore the theme of Sons and Lovers from D.H. Lawrence own view on life, that is, the pursuit of the true life and the integrated self. The significance of penetrating deep into the true-life-pursuit theme of the novel lies in the fact that the life diversity could be revived to enlighten people's lives who have been frustrated in their mechanized complexes.
\end{abstract}

\section{Keywords: Sons and Lovers, theme, true life, life flame}

\section{INTRODUCTION}

Sons and Lovers is one of D. H. Lawrence's masterpieces that make him well known in the literature circles in 20th century. "With his third novel Mr. Lawrence has come to full maturity as a writer," (Draper, P58-59). This highly autobiographical novel brings about uniqueness in its theme. Many scholars attempt to interpret it from the Freudian psychoanalytical perspective and regard the novel as the portrayal of Oedipus love between mother and son. Yet ,that does not speak the essence for the novel and Lawrence's real intent in artistic creation. Therefore, this paper will explore the theme of Sons and Lovers from D.H. Lawrence own view on life, that is, the pursuit of the true life and the integrated self. The negativities of mechanized civilization that bring about the separation of lives and self-disturbing complexes (Oedipus complex, instinct impulse, religious complex) — are the life obstacles Lawrence and his novel try to transcend, instead of having them as the theme or his spiritual pursuit in the novel. The development of the story is the process during which the conflicts between (Paul's) nature of life and mechanized civilization occur, develop and are solved. Furthermore, it's also a life-reborn process, in which the mechanized civilization is exposed, criticized and transcended.

What is the theme of Sons and Lovers? This is a quite disputable question. Some critics would like to apply Freud's methods and conclusions of psychoanalysis to understand the theme of Sons and Lovers and D. H. Lawrence's spiritual pursuit. They confine the themes of the novel and D. H. Lawrence's spiritual pursuit to the psychological concepts of Freud's, such as "Oedipus complex", "unconsciousness" and "sexual instinct", etc. D. H. Lawrence himself does not agree with their way of perceiving him and his work. He thinks that merging into the real life and regaining the true and integrated self are the theme of Sons and Lovers, even of all his creations.

\section{II. "LIKE LIFE, BUT ALWAYS MY THEME"}

In the letter to Garnett in 1912, after D. H. Lawrence briefly describes the story of the novel, he points out clearly: "It is a great tragedy, and I tell you that I have written a great book. It's the tragedy of thousands of young men in England... Now tell me if I haven't worked out my theme, like life, but always my theme" (Rylance, P49). Then, what does "life" mean in Lawrence's eyes? "By life, we mean something that gleams, that has the fourth dimensional quality. If the bank-clerk feels really piquant about his hat, if he establishes a lively relation with it, and goes out of the shop with the new straw on his head, a changed man, be-aureoled, then that is life...The ordinary bank-clerk buying himself a new straw hat isn't 'life' at all: it is just existence, quite all right, like everyday dinners: but not 'life' "(Lawrence, Morality and the novel, 1985, P173). "A thing isn't life, just because somebody does it", such as the sexual life between men and women, "if a man establishes a living relation to her, if only for one moment, then it is life. But if he doesn't: if it is just money and function, then it is no life, but sordidness, and a betrayal of living"(P174). 
Lawrence shows us that a person has life only when he possesses vitality, and when he loses it, he dies. As Julian remarks that people cannot deny the fact that life relies on vitality to an extreme degree (Julian, P391). Life is a kind of new relationship exceeding the rigid and illusory old ones, which are established among people or between people and things.

If people want to find back their true lives, they must experience all sorts of tortures, fighting and rebirth in which the old relations are broken down and the new ones are established, because the theme of life just lies in the process of experiencing such tortures, fighting and rebirth. "Each time we strive to a new relation, with anyone or anything, it is bound to hurt somewhat. Because it means the struggle with and the displaying of old connections, and this is never pleasant. And moreover, between living things at least, an adjustment means also a fight; for each party, inevitably, must 'seek its own' in the other, and be denied. When, in the two parties, each of them seeks his own, her own, absolutely, then it is a fight to the death" (P174).

In Sons and Lovers, a series of struggles in surface can be seen among the one-sided selves who are fettered by the old relations: Paul, the protagonist relies on his mother excessively and even falls in love with her; Mrs. Morel controls and shapes her son Paul according to her own pattern; and Paul attempts to possess Miriam and Clara completely; meanwhile Miriam and Clara also try to possess entirely something in Paul that belongs to them respectively, etc. We can easily see the Oedipus complex in the relation between Paul and his mother, the religious complex from the relation between Paul and Miriam and instinct impulse complex from the contacts between Paul and Clara. These old relations are complexes that distort people's true relations and true lives. Hence, can we sum up the theme of Sons and Lovers as an Oedipus complex or its like? Definitely, no. The purpose of D. H. Lawrence's description of the protagonist's spiritual pains, frustrations and struggles in the old complexes is not to stop in the old complexes, yield to those complexes, or even advocate the old relationships and old complexes. Instead, it is to break down the old relationships, set up new ones and step out of the old living conditions towards the new life. The descriptions of such scenes in the novel as that Paul curses the death of his mother, just reflect the life pursuit of Paul and his prototype Lawrence - to bury the old relationships and walk towards the new life.

\section{III. "UNCONSCIOUSNESS" THEORY AND TRUE LIFE}

Why D. H. Lawrence doesn't approve that people should apply Freudian theories to explain the life theme in Sons and Lovers? Because the idea of explaining life theme from the already existing theories or notions will easily mislead us to tailor life by theories, tailor life to theories, and the relationship between life and theories will be reversed. Lawrence points out that adjusting life to a certain theory mechanically, this method in itself is a mechanical process, a process of unconsciousness oppression and an idol replacing procedure...Freud's theory of unconsciousness and incest motive theory are useful and valuable in describing the inner condition. But once you apply them, and make them dominant in life, you are just starting to replace one mechanical or unconscious hallucination with another (Zhang Huai Jiu, P69).

The more important reason why Lawrence doesn't agree with the way of understanding or analyzing Sons and Lovers by Freud's theories lies in the fact that the core concept embodying the life theme of Sons and Lovers - intact life and true ego, has fundamental different connotation from the nuclear notion of Freudian psychology unconsciousness. Indeed, many plots in Sons and Lovers and some concepts in D. H. Lawrence's theories do share certain similarities with Freud's "unconsciousness", "sexual instincts " and "Oedipus complex", and Lawrence surely gives certain affirmations and positive opinions to such Freudian notions. However, each of them has different study objects and pursues different goals, which makes D. $\mathrm{H}$. Lawrence and Freud different greatly in attitudes and understandings of these concepts. Freud makes people's inner activities as his study objects, and his concepts such as "unconsciousness" or "sexual instinct" belong to the psychological category (These concepts function well in analyzing the psychological novels which aim to present the truth of people's inner world), their indication refers to "the cellar in which the mind keeps its own bastard spawn"(Lawrence, Psychoanalysis and the unconscious, P82), presenting the "dark side" of people's psyche. Hence, Freud identifies his "unconsciousness" as "disaster of the civilized society", and the impulse of sexual instinct , therefore it is " the cause of all evils". His purpose of revealing "unconsciousness" and "sexual instinct" is to control "unconsciousness" by consciousness and mediate "sexual instinct" by reason. Freud regards "unconsciousness" and "sexual instinct" as something that human beings is born with, something that conflicts with human beings' civilization, while they can't be dispelled. Hence, the oppression of "unconsciousness" and "sexual instinct" is the price human civilization must pay. Freud believes that people's unconscious condition is ego, conscious condition is the Id, and the moral norm of the society is super ego. Hence Id would always stay in the contradicted condition between ego and super ego. Starting from the psychological angle, Freud describes for us the 
dilemma of the separation between ego and super ego, between spirit and body, but he fails to find a way out of the predicament. The "flame of life" and intact self — the power and aim in life for people to overcome the predicament of the unilateral self, are absent in Freud's theory.

D. H. Lawrence have people and people's lives as his study objects. It is true that Lawrence also speaks about the "unconsciousness", "sex" or "sexual instinct", and he also reveals people's life predicament from the conflicts between people's natural instincts and mechanized civilization. These are reflected lively in the conflicts among characters in the novel, such as Mrs. Morel, Paul, Miriam, Clara, etc, also in the descriptions of many plots in which every character struggles in the unilateral self and one-sided emotional communication. However, because of the posing and intervention of the new and essential elements presenting the true life: human nature - nature of life - perpetual life flame — intact life ourselves - flow of life, the indication and function of such notions as "unconsciousness", "sex", "sexual instinct" and their relevant concepts "sexual relations", "Oedipus complex", etc., and people's attitudes towards these notions have fundamental difference from Freud's principles.

D. H. Lawrence thinks that the essential meaning of "sex" lies in people's true life, he tells people: "And what is sex, after all, but the symbol of the relation of man to woman, woman to man? And the relation of man to woman is wide as all life. It consists in infinite different flows between the two beings...chastity is part of the flow between man and woman, as to physical passion...The long course of marriage is a long event of perpetual change, in which a man and a woman mutually build up their souls and make themselves whole...But we are so foolish, and fixed by our limited ideas"(Lawrence, We need one another, P193). People's life nature, life relations, life flows, and intact life, these are D. H. Lawrence's soul, the root and source of Sons and Lovers and other novels of Lawrence, and also the light illuminating all things. Hence, every plot and concept bear the mark of this light, and should be understood under the guide of such light.

\section{RETURNING TO TRUE LIFE}

D. H. Lawrence also compares life nature to the "flame of life": "But there is a flame or a life everlasting wreathing through the cosmos forever and giving us our renewal, once we can get in touch with it"(Lawrence, The real thing, P202). "It is when men lose their contact with this eternal lifeflame, and become merely personal things in themselves, instead of things kindled in the flame, that the fight between man and woman
begins"(Lawrence, The essays of D. H. Lawrence, P76). "And then there is nothing for men to do but to turn back to life itself. Turn back to life that flows invisibly in the cosmos, and will flow forever, sustaining and renewing, all living things. It is not a question of sins or morality, of being good or being bad. It is a question of renewal, of being renewed, reborn, revivified? That is the question men must ask themselves, and women too" (Lawrence, The real thing, P202). D. H. Lawrence tells us a completely different principle from Freud's, that is, something perpetual is lifeflame, which is the nature of life, relation of life and the flow of life of human beings. And "unconsciousness" or "sexual instinct" is only part of this life flow, and they are relative, not perpetual or absolute. Once they are regarded as something perpetual as the way Freud treats, they will become "hallucination of unconsciousness", rigid ideas, concepts or words that cover up the nature of life, and the mechanized civilization complexes that distort the self.

Mechanized civilization complexes are not human beings' perpetual nature, and people's life nature has not been covered up by mechanized civilization complexes from the beginning. It is the mechanized civilization that brings about the mechanized civilization complexes and causes the distortion to the nature of life. Human beings' mission is to throw off the mechanized civilization complexes, merge into the flow of life and turn the rebirth of life into reality. Though both $\mathrm{D}$. H. Lawrence and Freud describe the conflicts and dilemma between human beings' natural instinct and mechanized civilization, what makes Lawrence different from Freud and more brilliant than him is that he offers people a way, a kind of true life power and aim to bury all those complexes and the unilateral self, and to return to the intact self. In Sons and Lovers, after Paul, the protagonist experiences the conflicts and struggles against Oedipus complex, religious ascetic complex and instinct impulse complex, in the end he floats to the direction where the one sided self dies and true life gets the rebirth... The development of the story, is just the course where Paul and its prototype Lawrence have their selves in reality merge into the life flow, and is also the process where the life theme in Sons and Lovers can be exhibited.

\section{LIGHTENING LIFE IN THE ANIMATE RELATIONSHIPS}

Then, are the fourth dimensional life and the eternal life flame D. H. Lawrence pursues something mysterious and obscure? Are they also an unconscious hallucination? This is a question that concerns many people. Lawrence reveals the account of life flame from the contrast between varied practical life demands from people in reality 
and the stereotyped conceptions. He writes in his 17,January 1913's letter to Earnest Collins: "We have got so ridiculously mindful, that we never know that we ourselves are anything - we think there are only the objects we shine upon. And there the poor flame goes on burning ignored, to produce this light. And instead of chasing the mystery in the fugitive, half lighted things outside us, we ought to look at ourselves... A flame isn't a flame because it lights up two, or twenty objects or a table. It's a flame because it is itself. And we have forgotten ourselves...the real way of living is to answer to one's wants... for the living of my full flame - I want that liberty, I want that woman, I want that pound of peaches, I want to go to sleep, I want to go to pub, and have a good time, I want to look a beastly swell today, I want to kiss that girl, I want to insult that man - Instead of that, all these wants, which are there. Whether-or-not, are utterly ignored, and we talk about some sort of ideas" (George, 1982, P53-54).

The perpetual life flame, life relations and life flows are not mysterious at all, and they just exist in all our varied and mobile life demands in real life. We can touch upon the perpetual life flame from the actual demands in life, in spirit and in sex. Then in what way can we touch upon the life flame and the animate life? D. H. Lawrence tells people: "He must have a quick relatedness to all the other things in the novel: snow, bed-bugs, sunshine, the phallus, trains, silk-hats, cats, sorrow, people, food, diphtheria, fuchsias, stars, ideas, God, tooth-paste, lightening, and toilet paper. He must be in quick relation to all these things. What he says and does must be relative to them all."(Lawrence, Phoenix II, 1978, P420) This is no mystery indeed. However, for people bogged down in the old relations of the mechanized civilization, it is definitely not an easy thing to break down the ties with the old relationships, touch the life flame and have their true life revived.

\section{CONCLUSION}

Consequently, the pursuit of true life is the eternal theme of Sons and Lovers, and the significance of penetrating deep into the true-lifepursuit theme of the novel lies in the fact that the life diversity could be revived to enlighten people's lives who have been frustrated in their mechanized complexes.

\section{References}

[1] Beal, A. D. H. Lawrence. New York: Evergreen Pilot Series. 1961.

[2] Becket, F. The complete critical guide to D. H. Lawrence. London; New York: Routledge. 2002.

[3] Beebe, M. Ivory Towers and Scared Founts. New York: New York University Press. 1964
[4] Black, M. D. H. Lawrence: the early fiction: a commentary. London: The Macmillan Press. 1986.

[5] Boulton, T. J. The selected letters of D. H. Lawrence. Cambridge: CUP. 1996

[6] Daiches, D. The Novel and the Modern World. Chicago: The University of Chicago Press. 1960.

[7] Dorothy, V. G. On Sons and Lovers. The English Novel: Form and Function. New York: Holt, Rinehart and Winston Inc., Publishers. 1953.

[8] Draper, R. P. D. H. Lawrence. New York: Twayne Publishers. 1964.

[9] Draper, R. P. ed. D. H. Lawrence: The critical Heritage. New York: Barnes and Noble. 1970.

[10] Frank O'C. The Mirror in the Roadway. London: A.D.Peters \& Co. and Miss Cyrilly Abels. 1955.

[11] Gamini, S, eds. Sons and Lovers: a casebook. London: Macmillan. 1969

[12] Georgey, Z. \& J. T. Boulton, eds. The letters of D. H. Lawrence. Volume II. Cambridge: CUP. 1982.

[13] Helen, B. \& C. Boron, eds. Forward part. Sons and Lovers. Cambridge: CUP. 1992.

[14] Hough, G. The Dark Sun: A Study of D. H. Lawrence. New York: Macmillan Co. 1957.

[15] Kermode, F. D. H. Lawrence. New York: Viking Press. 1973.

[16] Lawrence, D.H. Fantasia of the Unconscious. London: CUP. 1923

[17] Lawrence, D.H. The Novel. Study of Thomas Hardy and other essays. London: CUP. 1985.

[18] Lawrence, D.H. The novel and the feelings. Study of Thomas Hardy and other essays. London: CUP. 1985.

[19] Lawrence, D.H. Morality and the Novel. Study of Thomas Hardy and other essays. London: CUP. 1985.

[20] Lawrence, D.H. Why the novel matters. Study of Thomas Hardy and other essays. London: CUP. 1985.

[21] Lawrence, D.H. Edited by Edward D. McDonald. We need one another. Phoenix: the posthumous papers of D. H. Lawrence. New York: The Viking Press. 1936.

[22] Lawrence, D.H.1936. The real thing. Phoenix: the posthumous papers of D. H. Lawrence. Edited by Edward D. McDonald, New York: The Viking Press.

[23] Lawrence, D.H. Phoenix II. New York: Penguin books. 1978.

[24] Lawrence, D.H. Psycholoanalysis and the Unconscious. New York: Thomas Seltzer. 1921.

[25] Lawrence, D.H. Sons and Lovers. Hertford shire: Wordsworth. 1993

[26] Frieda, Lawrence. Not I, But the Wind. New York: Viking Press. 1934.

[27] Murry, J.M. Son of Woman. The society of Authors 22:98. 1931

[28] Pinion, F.B. A D. H. Lawrence Companion. London: The Macmillan Press. 1978.

[29] Ruderman, J. D. H. Lawrence and the devouring mother: The search for a Patriarchal Ideal of leadership. Durham, N.C.: Duke University Press. 1984.

[30] .Rylance, Rick. New casebooks: Sons and Lovers. New York: St. Martin's Press. 1996.

[31] Showalter. E. New Women. Sexual Anarchy 52:38.

[32] 1991.Simpson, Hilary. 1982. D. H. Lawrence and feminism. Worcester: Croom Helm Ltd.

[33] Spilka, Mark. 1957. The love ethic of D. H. Lawrence. Bloomington: Indiana University Press.

[34] Tony, Pinkney. 1990. D. H. Lawrence. Hemel :Hempstead 